\title{
Mitochondrial DNA depletion syndrome, hepatocerebrorenal form
}

INSERM

\section{Source}

INSERM. (1999). Orphanet: an online rare disease and orphan drug data base.

Mitochondrial DNA depletion syndrome, hepatocerebrorenal form. ORPHA:363534

\#64258;exia, ataxia, sensory neuropathy, epilepsy, sensorineural hearing impairment, psychomotor regression, athetosis, nystagmus, and/or ophthalmoplegia. Patients typically present with recurrent vomiting, severe failure to thrive, feeding difficulties, and fasting hypoglycemia. 